\title{
PÁrhuZAMOS TÖRTÉNETEK
}

\author{
TÓTH MIKLÓS BÁLINT
}

Budapesti Corvinus Egyetem, Politikatudományi Doktori Iskola

Andrzej Bolesta (ed.): Post-Communist Development: Europe's Experiences, Asia's Challenges. Warsaw, 2017. Collegium Civitas. 240 p. ISBN: 978-83-61067-59-7

Milyen hasonlóságot fedezhetünk fel Lengyelország és Mianmar, Csehország és Laosz, Szlovákia és Kambodzsa vagy éppen Magyarország és Vietnam között? $\mathrm{Az}$ Andrzej Bolesta szerkesztette tanulmánykötet állítása szerint a fent felsorolt, első látásra oly sok szempontból különböző országokat egyértelműen összeköti a posztszocialista transzformáció közös élménye. Ahogy a bevezetőben is olvashatjuk, a könyv azt az angolszász világban elterjedt megközelítést kívánja árnyalni, amely éles választóvonalat húz az Âzsiatanulmányok és a posztszovjet tanulmányok közé, és ennek megfelelően úgy látja, hogy igenis érdemes összevetni az előbb említett kelet-közép-európai és délkelet-ázsiai posztszocialista államokat. Sőt továbbmegy: meglátása szerint az előbbi országcsoportnak az átmenet során gyüjtött tapasztalatai értékes és hasznosítható tudást jelentenek azon ázsiai országok számára, amelyek még csupán a folyamat elején tartanak.

$\mathrm{A} z$ első tanulmányban a kötet szerkesztője a posztszocialista fejlesztő állam (postsocialist developmental state) fogalmán keresztül vizsgálja a délkelet-ázsiai országok fejlődését. Ahogy a kifejezés is mutatja, ezen elképzelés arra utal, hogy az államnak jelentős szerepe van a szocialista berendezkedést követő átmenet során. $\mathrm{A} z$ elemzés során arra jut a szerző, hogy legfőbb jellemzői a következők: 1) „sokkterá- pia" helyett a fokozatos gazdasági liberalizáció híve, habár privatizáció formájában jelentős állami vagyont ad külföldi kézbe; 2) a központi tervezés mechanizmusát felváltja a piacgazdaság keretei közt müködő „racionális tervezés” gondolata; 3) a keleteurópai gazdasági átmenetekkel szemben az állam marad a fejlődés motorja. Ezt követően a szerző először tágabb keretbe helyezve a kérdést áttekinti az ázsiai posztszocialista transzformáció fóbb vonásait, majd szúkíti a vizsgálat fókuszát, és Kína, Vietnam, Laosz és Mianmar fejlődését veszi górcső alá. Jól látható, hogy a kínai fejlődést tekinti követendő példának a másik három ország. Közös bennük, hogy a fokozatos liberalizáción alapuló gazdaságpolitika jelentős növekedést eredményezett, azonban a korábbi időszakra jellemző autokratikus hatalomgyakorlás érdemben nem változott; politikai enyhülés jelei az elmúlt évtizedben kizárólag Mianmarban figyelhetők meg. Ami a külföldi befektetőkhöz füződő viszonyukat illeti, ott egy sajátos „húzd meg, ereszd meg" játék észlelhető, hiszen miközben törekednek a külföldi tőke bevonzására, a gazdasági nacionalizmus ideológiájával összhangban adminisztratív korlátokat gördítenek eléjük.

A második fejezetben Michał Lubina a lengyel és a mianmari politikai átmeneteket veti össze. Fontos párhuzamot vél felfedezni abban, hogy a régi és az új politikai 
elit mindkét esetben egyfajta kompromisszumos megegyezésnek köszönhetően békés, vérontás nélküli úton terelte, tereli az országot a liberális demokrácia irányába. Először az 1989 februárjában kezdődő lengyelországi kerekasztal-tárgyalásokat mutatja be, mely során a kommunista vezetőréteg és az ellenzék lefektette a politikai átalakulás kereteit. Ez a megoldás mindkettejük számára előnyös volt: míg az előbbi a legitimációhiányt és a rossz gazdasági teljesítményt kívánta ellensúlyozni, addig az utóbbi így próbált hatalmi pozícióhoz jutni és elérni a (fél)szabad választások kiírását. Hasonló folyamatok indultak 2011-ben Mianmarban, amikor a hadsereg dominálta korábbi elit és az Aung Szán Szu Csí vezette ellenzék egymással kooperálva indították meg a politikai liberalizációt. Az események politikatörténeti bemutatása után a szerző kiemeli az Amerikai Egyesült Államok szerepét a folyamatokban, ezt követően pedig rátér a kompromisszumos átmenet társadalmi hatásainak elemzésére. Megemlíti az árnyoldalakat is, vagyis azt, hogy a korábbi rendszer kedvezményezettjei az akkor szerzett pozícióikat Lengyelországban és Mianmarban is sok esetben képesek voltak értékes gazdasági erőforrásokra váltani a rendszerváltás után, azonban a szerző ezt a jelenséget szükséges rossznak, azaz a gazdasági átalakulás és a békés átmenet kényszerü velejárójának tartja.

A következő tanulmányban Natthanan Kunnamas három volt jugoszláv tagköztársaság, Szlovénia, Horvátország és Szerbia posztszocialista transzformációját vizsgálja. Az első részben a Josip Broz Tito irányította Jugoszlávia történetét eleveníti fel, és utal arra, hogy már ekkoriban jelentős fejlettségi különbségek mutatkoztak az országban. Ezután rátér a Tito halála után fokozatosan bekövetkező válságra, az ország széteséséhez vezető folyamatra és a polgárháború időszakára. A történeti háttér felvázolása után a három választott utódállam politikai és gazdasági átmenetét elemzi. Megállapítja, hogy mindhárom országban jelentős eredményeket értek el a nemzetépítés, a többpártrendszer megteremtése és a civil társadalom erősítése terén, azonban a fejlődés dinamikája igencsak különböző. Szlovénia kiinduló pozíciója volt a legkedvezőbb, ennek megfelelően ott sikerült a leggyorsabban kiépíteni a liberális demokrácia és a piacgazdaság intézményrendszerét. Lemaradással ugyan, de Horvátország is követte nyugati szomszédját, és manapság mindkét állam az Európai Unió tagja. Velük szemben Szerbia szenvedte el legtovább a polgárháború következményeit, ugyanakkor a szerző által „fekete lóként” aposztrofált ország gazdasági fejlődési üteme felülmúlja a másik két országét. Ennek okát Kunnamas a követett modellek különbözőségében véli felfedezni: míg a szlovénok és a horvátok a fokozatos átmenetet preferálták, addig a szerbek „sokkterápiája” a fájdalmassága ellenére jobb növekedési eredményeket produkált. A tanulmány záró szakaszában a szerző kitér a nemzetközi hatásokra is, melyek közül kiemeli a NATO és az EU jelentőségét a térség stabilizálásában, illetve Szerbia kapcsán szót ejt az Oroszországhoz füződő intenzív kapcsolatokról is.

A következő fejezetben egy magyar szerzőpáros, Orosz Ágnes és Szunomár Ágnes írását olvashatjuk a kereskedelem és a külföldi befektetések Közép-Európában, közelebbről a visegrádi négyek országaiban betöltött szerepéről. Miután a szerzők ismertetik a V4-ek intézményesített együttmüködésének történetét, a gazdasági átmenet jellemzőit mutatják be. Kiemelik, hogy a posztkommunista államoknak három fó kihívással kellett szembenézniük: az ártámogatások többségének eltörlésével, a teljes foglalkoztatottság végével és az állami tulajdonú vállalatok profitorientált vállalkozásokká alakításával. 
A transzformációs válság után a V4-ek gazdaságai növekedési pályára álltak, amit az uniós integrációs folyamatok is támogattak. A 2008-as pénzügyi válság ugyan különböző mértékben, de mindegyik államot érintette: legerőteljesebben a magyar gazdaság érezte meg a hatásait, ezzel szemben Lengyelország volt az egyetlen EU-tag, amelynek nem kellett elszenvednie recessziót. Ezt követően veszik górcső alá a külkereskedelmi tendenciák változását, amely kapcsán három időszakot azonosítanak. Az első az 1980-as években kezdődött és 1994-ben ért véget. Ebben a fázisban a posztszocialista országokkal való kereskedelem a felére zsugorodott, ezzel együtt megnövekedett a nyugati kapcsolatok jelentősége. A második szakaszt a 2008-as világgazdasági válságig datálják: fô vonása a gazdasági nyitottság erősödése és a globális értékláncokba való bekapcsolódás, annak minden előnyével és hátrányával együtt. A pénzügyi krízis beköszöntét követően a külkereskedelmi mutatók a V4-ek esetében is visszaestek, de a 2009-es mélypont után az exportteljesítményük ismét javulni kezdett. Ezt követően külön alfejezetet szentelnek a külföldi közvetlentőke-befektetések (FDI) trendjei elemzésének. Rámutatnak arra, hogy az FDI mekkora szerepet játszott a gazdasági átmenet során, majd a tanulmány végén párhuzamot vonnak a V4-ek tapasztalatai és a CLMV-országok (Kambodzsa, Laosz, Mianmar, Vietnam) előtt álló kihívások közt. Fontos tanulság mindkét országcsoport számára, hogy a globális értékláncokban való előrelépés érdekében szükség van arra, hogy az olcsó munkaerő mint komparatív előny helyett egyre inkább a jól képzett humánerőforrásban lássák a gazdasági bővülés útját.

$\mathrm{A} z$ ötödik tanulmány szerzője, Günter Heiduk a regionalizáció jelenségét vizsgálja Németország és a visegrádi négyek viszonylatában. Ezen a téren két fordu- lópontot határoz meg. Az elsőt 1989-hez és a KGST felbomlásához köti, amely következtében megváltozott Magyarország, Lengyelország és akkor még Csehszlovákia gazdasági és politikai orientációja, és az újrafogalmazódó feltételek közt Nyugat felé kezdtek gravitálni. Az egyre szorosabbá váló relációk megerősödéséhez újabb lökést adott az Európai Unió 2004-es bővítése. Ebben a kontextusban válik érthetővé Németországnak a térség átalakulásában betöltött szerepe. Ahogy Heiduk írja, a folyamat mindkét fél számára előnyös volt. Németország a szoros kapcsolatok kialakításával bővítette piacait, és képes volt egy sajátos munkamegosztást (tudás- és munkaerő-igényes szektorok) létrehozni, ezen nexus pedig jelentősen hozzájárult a V4-ek nyugati integrációjához. Az FDI és a külkereskedelem kapcsolata ezen a téren is egyértelmü; legnyilvánvalóbb jelét az autóiparban fedezhetjük fel. A jelenség sajátosságait kitűnően feltárja azon esettanulmány, amelyben a szerző a Skoda Volkswagen általi akvizícióját mutatja be. Zárásképpen Heiduk összegzi a Mianmar számára releváns tapasztalatokat. Fontos tanulság, hogy a visegrádi négyek által létrehozott intézményesített együttmüködés remekül szolgálta az FDI bevonzását a régióba, azonban a hosszú távú fejlődés érdekében elengedhetetlen, hogy a döntéshozók nagy hangsúlyt helyezzenek a munkaerő képzettségi szintjét növelő közpolitikák támogatására.

A $z$ utolsó tanulmányt Piotr J. Szpunar jegyzi, aki a lengyel bankrendszer átalakulását mutatja be a posztszocialista átmenet kontextusában, és ez alapján néhány megfontolandó javaslatot fogalmaz meg a mianmari gazdaságpolitika számára. A lengyel gazdasági átmenet alapját jelentő „sokkterápia” értelemszerüen a pénzügyi szektorra is hatással volt. A modern piacgazdaságra való gyors áttérés érdekében rövid időn belül törvényi hátteret biztosí- 
tottak a vállalkozás szabadságának, kétszintűvé vált a korábban egyszintü bankrendszer, és liberalizálták a hitelkihelyezés feltételeit. Ezen lépések sikere ellenére a súlyos gazdasági recesszió komoly gondot okozott a bankrendszerben is; különösen a rosszhitel-állomány növekedése jelentett komoly nehézségeket. A központi bank aktív intervenciójának és a szigorúbb szabályozási környezet megteremtésének köszönhetően a bankszektor kikerült az egész gazdaságot veszélyeztető krízisből, és a megtisztulás útjára lépett. Az 1990 es évek végére stabillá váló lengyel bankszektor egyre vonzóbb lett a külföldi befektetők szemében, akik a támogató jogi környezetnek köszönhetően jelentős részesedést szereztek ezen a területen is. A felügyeleti rendszer hiányosságai azonban látványossá váltak, amikor kiderült, hogy az SKOK takarékpénztárak nem megfelelő hitelkihelyezési gyakorlata miatt felduzzadt a rosszhitel-állomány. A botrány kitörése után tovább szigorodott a szabályozás, és ennek eredményeképp a lengyel bankrendszer a gazdasági növekedés motorjává vált. Szpunar a fentiek alapján arra a következtetésre jut, hogy Mianmar esetében is kulcsfontosságú a pénzügyi szektor stabilitásának megteremtése, azonban fokozottan kell ügyelni arra, hogy a gazdasági átmenettel harmonizálva fejlödjön, ugyanis egy gyenge makroökonómiai mutatókkal rendelkező országot egy túlfütött pénzügyi rendszer könnyen maga alá temethet.
Annak ellenére, hogy a kötet számos megfontolandó érvet hoz fel arra nézve, miért érdemes összehasonlítanunk a kelet-európai és a délkelet-ázsiai posztszocialista transzformációkat, az olvasóban mégis felmerülhetnek kételyek az összevethetőségüket illetően. A történelmi és kulturális különbségek figyelmen kívül hagyása felveti az emberben a kérdést, hogy a kétségkívül meglévő hasonlóságok elegendő indokot jelentenek-e arra, hogy a régiónk tapasztalatait átültessük, ha úgy tetszik: exportáljuk Délkelet-Ázsia országaiba. A kötet megjelenése óta eltelt két év megerősíti ezt a bizonytalanságot. A világsajtó részéről nagy érdeklődésre számot tartó rohingya menekültválság is felhívja a figyelmet arra, hogy a nyugati világ politikai konstrukciói mennyire más fénytörést kapnak eltérő civilizációs környezetben. A kompromisszumos kerekasztal-tárgyalásokon alapuló átmenet Mianmar esetében történő értelmezésének érvényességét megkérdőjelezi, hogy az eseményekkel párhuzamosan véres etnikai villongások, sőt bizonyos vélekedések szerint egyenesen népirtás zajlott és zajlik az országban.

A fentiek ellenére a kötet újszerü problémafelvetése egyértelműen gazdagítja a posztszocialista átalakulásokról szóló irodalmat, és jelentősen hozzájárul annak a máig be nem fejezett folyamatnak a megértéséhez, amelyet kelet-közép-európaiként mi is megéltünk és megélünk.

A cikk a Creative Commons Attribution 4.0 International License (https://creativecommons.org/licenses/ by/4.0/) feltételei szerint publikált Open Access közlemény, melynek szellemében a cikk bármilyen médiumban szabadon felhasználható, megosztható és újraközölhető, feltéve, hogy az eredeti szerző és a közlés helye, illetve a CC License linkje és az esetlegesen végrehajtott módosítások feltüntetésre kerülnek. (SID_1) 